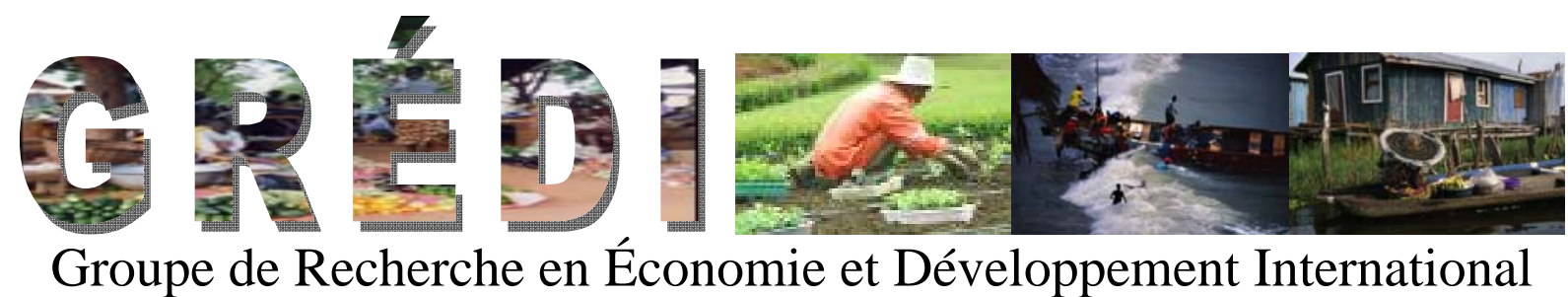

Cahier de recherche / Working Paper

09-24

\title{
HUMAN CAPITAL AND GROWTH: NEW EVIDENCES FROM AFRICAN DATA
}

Dorothée Boccanfuso

Luc Savard

Bernice Savy 


\title{
HUMAN CAPITAL AND GROWTH: NEW EVIDENCES FROM AFRICAN DATA
}

\author{
Dorothée Boccanfuso ${ }^{1}$, Luc Savard ${ }^{2}$ and Bernice E. Savy ${ }^{3}$
}

August 2009

\begin{abstract}
Economic theory long acknowledged a positive relation between human capital and economic growth (Smith, 1776; Becker, 1964), which was nevertheless called into question in the late 1990s (Caselli et al. 1996; Pritchett, 2001). The two primary criticisms evoked were the failure to consider diminishing returns to education and qualitative aspects of the stock of human capital. This work aims to redress inadequacies in the literature related to the usual proxy of human capital by advancing a composite indicator of human capital (PCA). This indicator allows for an integration of the qualitative aspects in question and uses the indicator of the stock of human capital (Mincer, 1974) to take diminishing returns into consideration. Adopting the methodology developed by Islam (1995) allows for the impact of human capital to become positive once again in the process of economic growth. The data also reveal a conditional convergence process for the 22 African countries considered over the period 1970 to 2000.
\end{abstract}

Keywords: Economic growth, human capital, convergence, Africa

Codes JEL : 018, O47, 055

${ }^{1}$ Professor, GREDI, Université de Sherbrooke, 2500 Boulevard Université, Sherbrooke (Québec) - J1K 2R1, Tel: 8198218000 \# 65169, Fax: 819 821-7934, Email : dorothee.boccanfuso@usherbrooke.ca.

${ }^{2}$ Professor, GREDI, Université de Sherbrooke, Email: luc.savard@USherbrooke.ca.

${ }^{3}$ GREDI, Université de Sherbrooke, Email: Bernice.Elvire.Vanes.Savy@USherbrooke.ca. 


\section{Introduction}

Understanding why certain countries are rich while others are poor constitutes one of the fundamental themes of development economics. The argument concerning the level of human capital has often been advanced to explain this duality. Its importance can in fact already be observed in Adam Smith's The Wealth of Nations (1776), in which the author pointed out that investment in capital enables an increase in future productivity. Smith asserted the importance of the role of education and training as a determiner of earnings and individual productivity. In the second half of the $20^{\text {th }}$ century, the work of Mincer (1958), Schultz (1961), and Becker (1964) once again emphasized the importance of human capital and presented an in-depth human capital theory. It is Becker (1964) who truly established the conceptual frame of the human capital theory. He formalized educational choices as rational choices of optimizing agents, who compare the present value of earnings to be expected from education and its related costs, over a life-cycle period.

The work of Lucas (1988) and of Mankiw, Romer, and Weil (1992) (MRW) brought new momentum to the debate on the relation between growth and human capital. In the late 1990s and early 2000s, some studies, such as those of Caselli, Esquivel and Fernando (1996) and of Pritchett (2001), nonetheless questioned this relation. Indeed, these authors observed no relation-and in some cases a negative relation-between the two. This led educational economists to highlight diminishing returns in education, as well as the importance of considering the quality of educational systems, in analyses. Consequently, considering the endogeneity of education in growth regressions, that is to say of educational quality indicators, as well as of its diminishing returns, contributed to a renewed acknowledgement of the positive role of human capital.

This context provides the backdrop for the present study. We will examine the impact of human capital on the process of economic growth by considering qualitative indicators and diminishing returns related to education for a sample of 22 African countries for the period 1970 to 2000 . Over the past two decades, the process of convergence of economies has also been the subject of numerous studies (Islam, 1995; Barro and Sala-i-Martin, 1992). Solow's neoclassical model (1956) predicted the convergence toward the same level of per capita GDP of countries that are similar in terms of technology and preference. Romer's theory of endogenous growth (1986) for its part affirmed the persistence of differences between levels of per capita GDP. We study this question based on our sample of African countries. Do the various differences in per capita GDP of African countries tend to diminish? How does 
the accumulation of human capital contribute to the convergence process? In the following section, we briefly recall the role of human capital in economic growth theory. The third section presents the characteristics of our analytical model as well as the data used. The results of our estimates are presented and analysed in section 4, followed by the conclusion (section 5).

\section{Human Capital in Growth Theory}

Human capital often plays a key role in various theories of economic growth and development. Becker (1974) considers that human capital can be seen as the whole of productive worker talents and competencies, whether acquired informally (via experience) or formally (via education or training). It can also be defined as the whole of investments such as education, health, and on-the-job training, which improve a person's productivity in the labour market and in other domains.

In economic theory, neoclassical and endogenous growth models underscore the importance of human capital in the development of an economy. Endogenous growth models advocate sustained and auto-maintained growth by endogenizing the choice of actors, sometimes in terms of capital investment, sometimes in terms of research and development. These various models can be grouped into two categories according to their approach to the relation between human capital and growth. ${ }^{4}$ The first category of models considers human capital as a factor of accumulation in the same way as physical capital in the production function; their accumulation should favour growth, so that differences in levels of human capital are tied to differences in production levels between countries. The second category of models considers that a greater stock of human capital primarily affects economic growth by facilitating the innovation and adoption of new technologies, so that differences in levels of human capital bring about differences in production growth in various countries.

In the early 1990s, many empirical studies on growth tended to confirm the positive role of education with regard to growth. Mankiw et al. (1992) examine whether Solow's growth model (1956) is consistent with international variation in living standards. They advance the augmented Solow model. The authors show that differences in saving, education, and population explain the differences in per capita income. They also find that poor countries tend to grow faster than rich countries, and show that countries with similar technologies,

${ }^{4}$ Cf. Aghion and Howitt (1998), Benhabib and Spiegel (1994) 
demographic growth, and rates of capital accumulation should converge, but at a slower rate than that predicted by Solow (1956). Barro (1991) considers that the change in the rate of secondary schooling from $50 \%$ to $100 \%$ (the order of magnitude of evolution in France between 1960 and 1985) increases the annual growth rate of earnings by approximately 1 percentage point.

In the mid 1990s, however, optimism concerning human capital and growth waned somewhat. Benhabib and Spiegel (1994) ask the following question: How does the human capital or education level of labour affect an economy's production and growth? These authors failed to find the positive relation described by Mankiw et al. (1992) between human capital and economic growth using a standard approach (that of MRW), which consists in treating human capital, measured through the average number of years of schooling of the labour force, as an ordinary production factor. Benhabib et al. (1994) propose an alternative approach associated with the endogenous growth theory. They model technological progress, or total factor productivity (TFP) growth, as a function of education level or human capital. The intuition is that educated labour is superior in its creation, application, and adoption of new technologies, all of which generates growth. These authors' results therefore question the traditional role ascribed to human capital in the development process as a separate production factor. In their alternative model, human capital influences TFP growth. They therefore arrive at the positive relation once again. In this model, human capital contributes to growth through two mechanisms. First, the level of human capital directly influences the locally produced technological innovation rate, as in Romer (1990). Second, the stock of human capital affects the rate of foreign technology adoption, according to the perspective of Nelson and Phelps (1966). Moreover, their model concludes in the catch-up effect between countries when the poorest can increase their stock of human capital and surpass that of the richest. In terms of empirical implications, the relevance of their model is that the stock of human capital (with regard to level), rather than its rate of growth, plays a significant role in determining the per capita GDP growth rate. Benhabib and Spiegel (1994) also show that in the richest countries, it may be the direct effect of education on innovative capacity that influences growth, while in the poorest countries, the catch-up effect comes into play. The impact of education on growth thus varies according to country development level.

Other empirical studies such as those of Pritchett (2001) and of Krueger and Lindahl (2001) also bring into question the general optimism of the early 1990s regarding education's contribution to growth. Krueger and Lindahl (2001) note that education is 
statistically significant and positively tied to growth only for countries with low education levels. Pritchett (2001) for his part finds no relation between the increase in human capital and the per capita GDP growth rate for his sample of developing countries. He offers three possible reasons for this. First, the political and institutional environment could be bad enough that the accumulation of human capital weakens economic growth. Second, education quality could be so low that years of schooling fail to create any level of human capital. Third, returns on education may have rapidly declined, the supply of educated labour having increased while demand remained stagnant.

Confronted with this wave of empirical studies that are unable to establish the positive role of human capital in growth, a number of authors have studied the subject to find satisfactory explanations for the somewhat "disturbing" results obtained in the late 1990s. In his review of the literature on human capital, Dessus (2000) offers a plausible explanation in the fact that educational system quality evolves differently from one country to another; consequently, accumulating raw human capital at the same rate could produce different results. He proposes an alternative formalization of the educational system's role in terms of the quality of human capital, which consists in supposing that the consideration of production function heterogeneity should be done through the marginal productivity of human capital. Dessus shows that the initial endowment of human capital available in the economy explains this heterogeneity of educational system quality. In so doing, he confirms the results of Azariadis and Drazen (1990), according to which rapid growth cannot occur without a high level of investment in human capital relative to per capita income.

Obtaining results on the relation between growth and human capital therefore seems to depend on the indicator used to characterize human capital. Wössman (2000) has proposed a review of human capital proxies used in the literature. Among these are the increased labour associated with education (qualified and non-qualified labour, for example) (Denison, 1967; Jorgenson, 1995); the literacy rate (Azariadis and Drazen, 1990; Romer, 1990); the average, primary, or secondary enrolment rate (Barro, 1991; Mankiw et al., 1992; Levine and Renelt, 1992); and the average number of years of schooling (Barro and Sala-i-Martin, 1995; Barro, 1997,1999; Benhabib and Spiegel, 1994). Wössman (2000) criticizes each of these indicators, as they only allow for a certain notion of the human capital included in the labour force. He thus suggests a new specification of human capital based on the Mincerian human capital theory and the quality index put forth by Hanushek and Kimko (2000). This new indicator enables a consideration not only of the quantitative aspect of human capital, but 
also of its quality, by considering these diminishing returns as well as the efficiency of the educational system.

It should also be noted that the increase in databases on growth and human capital measurement has favoured research on the contribution of human capital to growth. The databases of Barro and Lee $(1993,1996,2001)$ can be cited on this subject. Other relevant databases include those of Fuente and Doménech (2000), which deal with the OECD countries, the Penn World Table of Heston, Summers and Aten (2006), UNESCO's statistical yearbooks, the World Bank databases, and the tables of Pscharopoulos and Patrinos (2002) on the rates of return on education. With the availability of data that integrates both quantity and quality indicators of human capital, a new generation of empirical studies on growth and human capital has emerged in recent years.

Creel and Poilon (2006) examine the impact of human capital (measured by ordinary educational expenses) and of public investment on growth using an augmented Solow model. Human capital and public investment have proven to be driving forces in European economic growth. Another contribution that directly integrates the measure of educational quality into a growth model is that of Barro (2001). He uses an endogenous growth model and also observes the positive role of education as concerns growth in his sample of one hundred countries over the period 1960 to 1995 . These results show that the consideration of educational quality is more important than its quantity measured by average secondary and higher education completion. Altinok (2006) uses new indicators, based on international surveys on acquired student knowledge, to test the relation between education and growth. By considering the endogeneity of education, he comes to the conclusion of a positive effect, in terms of both quantitative and qualitative indicators of human capital, on the growth of a sample of 105 countries for the period 1960 to 2000.

In this article, we base our work on the neoclassical growth model developed by Islam (1995), which allows us to benefit from a study carried out using panel data. Furthermore, acknowledging Wössman's criticism (2000) pertaining to the human capital indicator, we consider diminishing returns and certain quantitative and qualitative aspects of human capital in order to assess the stock of human capital in a number of African countries. Our work thus consists in redressing inadequacies noted in the literature on the "average number of years of schooling" as a proxy of human capital in view of the rarity of available information pertaining to the African continent. We consequently propose a composite indicator of human capital that allows for a consideration of its qualitative aspects using a principal component analysis (PCA) to better evaluate its impact in the process of economic 
growth on a panel of African countries. This indicator allows us to measure the importance of education and therefore of human capital on the level and variation of per capita GDP of a sample of African countries using panel data and the methodology proposed by Islam (1995). Finally, we analyse convergence to find out whether the differences recorded in terms of per capita GDP between African countries tend to diminish. In the section that follows, we develop the method used to answer these questions.

\section{Methodology and Data}

As previously mentioned, the chosen analytical model is based on the model developed by Islam (1995), in which we will use two approaches to human capital evaluation.

\subsection{Analytical Model}

Islam's model (1995) is essentially a specification of the Mankiw et al. (1992) model, but using panel data. Mankiw et al. (1992) for their part take up the fundamentals of the Solow model, into which they integrate the concept of human capital. Two types of capital are included: physical capital and human capital. The production function is Cobb-Douglas:

(1) $Y(t)=K(t)^{\alpha} H(t)^{\beta}(A(t) L(t))^{1-\alpha-\beta}$ with $0<\alpha<1$ and $0<\beta<1$

where $K(t)$ denotes physical capital, $H(t)$ human capital, $L(t)$ work, and $A(t)$ technological advancement. Labour $(L)$ is assumed to increase to an endogenous rate $n$ due to population growth and the exogenous increase in labour productivity. Technological advancement $A$ is exogenous and grows at rate $g$. Moreover, the two forms of capital are assumed to depreciate to rate $\delta$. The model also assumes that a constant fraction of the population, $s_{j}$, is invested in each type of capital $j$. The evolution of physical and human capital expressed per capita is given by:

$$
\begin{aligned}
& \text { (2) } \dot{k}=s_{k} y_{t}-(n+g+\delta) k_{t} \\
& \text { (3) } \dot{h}=s_{h} y_{t}-(n+g+\delta) h_{t}
\end{aligned}
$$

The values of physical and human capital at the steady state are:

(4) $k^{*}=\left(\frac{s_{k}^{1-\beta} s_{h}^{\beta}}{n+g+\delta}\right)^{1 / 1-\alpha-\beta}$ 
(5) $h^{*}=\left(\frac{s_{k}^{\alpha} s_{h}^{1-\alpha}}{n+g+\delta}\right)^{1 / 1-\alpha-\beta}$

By substituting the expressions of $k^{*}$ and $h^{*}$ in the production function expressed per capita and in natural logarithm, we obtain:

(6) $\ln y^{*}=\ln A(0)+g t+\frac{\alpha}{1-\alpha-\beta} \ln \left(s_{k}\right)+\frac{\beta}{1-\alpha-\beta} \ln \left(s_{h}\right)-\frac{\alpha+\beta}{1-\alpha-\beta} \ln (n+g+\delta)+\varepsilon$

with $A(t)=A(0) e^{g t}$. After modification, we obtain Islam's productivity equation (1995), which assumes that countries are at the steady state, and which gives the relation between the level of per capita GDP $(y)$ and the demographic growth rate $(n)$, the saving rate $\left(s_{k}\right)$, the stock of human capital $(h)$, the growth rate of technological progress $(g)$, and the rate of depreciation $(\delta)$. For each country $i$, it is given by:

(7) $\ln y_{i}^{*}=\ln A_{i 0}+g t+\frac{\alpha}{1-\alpha} \ln \left(s_{k i}\right)+\frac{\beta}{1-\alpha} \ln \left(h_{i}^{*}\right)-\frac{\alpha}{1-\alpha} \ln \left(n_{i}+g+\delta\right)+\varepsilon_{i}$

Because we also wish to examine the existence of a convergence process, we consider the convergence equation developed by Mankiw et al. (1992) and taken up using panel data by Islam (1995). This equation loosens the constraints of the equilibrium hypothesis and provides the influence of variables such as the stock of human capital, the rate of demographic growth, and the rate of investment in human capital on the gap between current and equilibrium per capita GDP.

$$
\begin{aligned}
\ln y_{i}\left(t_{2}\right)=\left(1-e^{-\lambda \tau}\right) & \frac{\alpha}{1-\alpha} \ln \left(s_{k i}\right)-\left(1-e^{-\lambda \tau}\right) \frac{\alpha}{1-\alpha} \ln \left(n_{i}+g+\delta\right)+ \\
+ & \left(1-e^{-\lambda \tau}\right) \frac{\beta}{1-\alpha} \ln \left(h_{i}^{*}\right)+e^{-\lambda \tau} \ln y_{i}\left(t_{1}\right) \\
& +\left(1-e^{-\lambda \tau}\right) \ln A_{i}(0)+g\left(t_{2}-e^{-\lambda \tau} t_{1}\right)
\end{aligned}
$$

where $y_{i}\left(t_{1}\right)$ denotes initial earnings per worker for countries $i, \tau=\left(t_{2}-t_{1}\right)$ and $\lambda=(n+g+\delta)(1-\alpha)$. By grouping these terms and synthesizing this last equation, we obtain the following:

$$
\text { (9) } y_{i t}=\gamma y_{i, t-1}+\sum_{j=1}^{3} \beta_{j} x_{i t}^{j}+\eta_{t}+\mu_{i}+v_{i t} \text {, where }
$$




$$
\begin{aligned}
& y_{i t}=\ln y_{i}\left(t_{2}\right) \\
& y_{i, t-1}=\ln y_{i}\left(t_{1}\right) \\
& \gamma=e^{-\lambda \tau} \\
& \beta_{1}=\left(1-e^{-\lambda \tau}\right) \frac{\alpha}{1-\alpha} \\
& \beta_{2}=-\left(1-e^{-\lambda \tau}\right) \frac{\alpha}{1-\alpha} \\
& \beta_{3}=\left(1-e^{-\lambda \tau}\right) \frac{\beta}{1-\alpha} \\
& x_{i t}^{1}=\ln \left(s_{k i}\right) \\
& x_{i t}^{2}=\ln \left(n_{i}+g+\delta\right) \\
& x_{i t}^{3}=\ln \left(h_{i}^{*}\right) \\
& \mu_{i}=\left(1-e^{-\lambda \tau}\right) \ln A_{i}(0) \\
& \eta_{t}=g\left(t_{2}-e^{-\lambda \tau} t_{1}\right)
\end{aligned}
$$

Equation (9) is based on an approximation around the equilibrium state and captures the dynamics surrounding this equilibrium. It is therefore valid for short time periods. It can also be noted that for a cross-section regression, $s_{k}$ and $n$-that is to say the rate of investment in physical capital and the rate of demographic growth-are assumed constant over the entire period. Such an approximation is therefore more realistic over short time periods. The panel-based analysis is made possible by dividing the analysed period into short intervals; we will use intervals of five years, as in Islam (1995). By considering the period from 1970 to 2000, we obtain six dates for each country, namely 1975, 1980, etc. until $2000 .^{5}$ The approach using panel data allows for both the control of specific effects by country, and the integration of the convergence process, produced over several consecutive time intervals.

The value of $\lambda$ represents the convergence speed, the rate at which each economy reaches its steady state of equilibrium when its point of departure represents a situation of disequilibrium while assuming that its structural characteristics remain unchanged during the transitional period. If we consider that the shares of earnings factors are constant, then the higher the demographic growth rate, the faster the convergence, ceteris paribus. A country's per capita income growth rate depends on the level where these earnings are situated in relation to the economy's long-term equilibrium path: a country records an even higher per capita growth rate when further from its long-term equilibrium path. An inverse relationship (see Solow, 1956) exists between the per capita growth rate and initial per

\footnotetext{
${ }^{5}$ Thus when $t=1990$, we obtain $t-1=1985$.
} 
capita GDP inasmuch as different structural characteristics (investment rate, population growth rate, technology level, etc.) between countries are taken into consideration. This relation shows that the absence of convergence of per capita earnings comes from structural characteristics. In these circumstances, if we obtain an estimated coefficient for the initial value of the per capita product with the minus sign, we can say that in our sample, the economies belonging to the group of poorest economies are not in a situation of stationary equilibrium and will even grow, on average, faster than the richest economies.

For the estimates of equations (7) and (9), we must again specify the evaluation approaches of the stock of human capital. As previously mentioned, we propose two approaches to consider human capital in our model.

The first consists in evaluating the stock of capital by taking into consideration the diminishing returns to education. According to Psacharopoulos (1994), the study of salary differences shows diminishing returns in education. This means that an additional year of schooling for a worker will also depend on the number of years of schooling already realized by this worker. Since years of schooling cannot simply be added (at the margin their contribution to production is not the same), it is necessary to refer to the human capital theory to functionally relate human capital measured in monetary units with years of schooling. For this we will use the Mincerian specification based on the human capital theory. This theory assumes that annual salaries received by a worker with $s$ years of schooling are a linear function of years of schooling. An additional year of schooling will raise the worker's salary by $r$ percent. It is thus possible to construct an indicator of human capital based on the return on years of schooling. First of all, by considering that the return is the same:

(10) $H_{\text {Mincer }}=e^{\phi(s)} L$ with $\phi(s)=r s, \phi^{\prime}(s)=r$ and $\phi(0)=0$

where $\phi(s)$ is a function expressing the labour efficiency of a qualified worker with $s$ years of schooling. According to the more accurate hypothesis that the rate of return depends on years of schooling completed by the worker for each level of schooling, Equation Erreur! Source du renvoi introuvable.) can be rewritten as follows:

$$
H_{\text {Mincer }}=e^{\sum_{a} r_{a} s_{a}} L \text { with } \phi(s)=\sum_{a} r_{a} s_{a}
$$

with $r_{a}$ as the rate of return on education at level $a$ and $s_{a}$ as the number of years of schooling at level $a$. 
By knowing the years of schooling at different levels and basing our work on estimates made on rates of return on education (primary, secondary, and higher) in Africa by Psacharopoulos and Patrinos (2002), we can establish a measure of human capital based on the Mincerian specification.

The second approach we have chosen consists in integrating the qualitative aspects of human capital. To do so, we have preceded to a principal component analysis ${ }^{6}$ (PCA) using different qualitative indicators in order to determine a composite indicator of human capital. The database of Barro and Lee (2001) offers a series of indicators involving the various inputs of an educational system. Among these are the student-teacher ratio, public expenses per student, the share of public expenses per student in the per capita GDP, average teacher salary, etc. These indicators have allowed us to get an idea of the quality of educational systems for the countries studied. Once the composite indicator is constructed, we can introduce it into our model to assess the qualitative aspect of the educational system along with the usual proxy of stock of human capital-the average number of years of schoolingwhich better assesses the quantitative aspect.

3.2. Data

To carry out our research, we have used several databases on the African countries in question covering the period between 1970 and 2000. Twenty-two countries have been chosen for study based on information availability on indicators used during the mentioned period. The first database is the Penn World Table (PWT) version 6.2 established by Heston, Summers and Aten (2006), from which we have extracted information on GDP and the variables of physical capital and population. The second database is that of Barro and Lee (2001), which provides information on both quantitative and qualitative aspects of human capital. To complement the data on the indicators of human capital for the sample of African countries, we have used the education-related databases of UNESCO as well as those found on the World Bank website. Next we used the results of the estimates of Pscharopoulos and Patrinos (2002) on social returns of various education levels for the sub-Saharan and Northern African countries. As mentioned earlier, this indicator enables us to estimate the stock of human capital using the Mincerian method (Equation (11)).

Before presenting the results of our analysis, we present in Table $1^{7}$ some of the descriptive statistics relating to selected data. It appears that the average per capita GDP of

\footnotetext{
${ }^{6}$ The results of the analysis can be found in the appendix (cf. 0). For a more detailed explanation of the method, see Volle (1997).

${ }^{7}$ The statistics per country can be found in the appendix, in Descriptive Statistics by Country
} 
our sample of 22 African countries (in PPP dollars at the constant prices of 2000) went from $\$ 1,414$ in 1970 to $\$ 2,056$, that is to say an annualized growth of more than $3.5 \%$ over 30 years. The highest per capita GDP values are \$4,305 in 1970 held by Algeria and \$6,556 in 2000 held by Botswana. The average per capita GDP did not in fact double in 30 years $(31.2 \%)$, contrary to the country populations, which more than doubled during this period $(52.4 \%)$.

When it comes to data on education, the average number of years of schooling of our sample is 1.63 years, that is to say less than 2 years in 1970 and 3.48 years in 2000. In this same year, the highest number of years of schooling in our sample is 6.28 years in Botswana while the lowest number of years of schooling (0.84 years) is in Guinea-Bissau. We also observe a slight improvement in terms of the average number of students per teacher in primary school over the period, which ranges from 44.5 students per teacher in 1970 to 42.15 en 2000 . The average number of secondary school students rose by $13.41 \%$ over the same period. Other indicators also deteriorated. This is the case for the average primary school teacher salary, which diminished over 30 years, from $\$ 5,689$ in 1970 to $\$ 5,511$ in 2000 (a drop of 3.11\%); the same is true of public expenses per primary student in per capita GDP, which fell from $19.14 \%$ to $12.84 \%$. Following this brief data analysis, we present in the next section the results of our estimates in order to assess the role of human capital in the growth and convergence process.

Table 1: Descriptive statistics

\begin{tabular}{|c|c|c|c|c|c|c|c|}
\hline \multirow{2}{*}{ Variables $^{8}$} & \multicolumn{4}{|c|}{ Mean } & \multicolumn{2}{c|}{ Minimum } & \multicolumn{2}{c|}{ Maximum } \\
\cline { 2 - 8 } & 1970 & 2000 & Ecart & 1970 & 2000 & 1970 & 2000 \\
\hline$\hat{h}$ & 1,63 & 3,48 & $113,50 \%$ & 0,30 & 0,84 & 3,40 & 6,28 \\
\hline$\hat{h}^{\text {Pri }}$ & 1,39 & 2,57 & $84,89 \%$ & 0,26 & 0,69 & 3,32 & 4,76 \\
\hline$\hat{h}^{\text {Sec }}$ & 0,22 & 0,84 & $281,82 \%$ & 0,01 & 0,14 & 1,31 & 1,90 \\
\hline$\hat{h}^{\text {High }}$ & 0,01 & 0,07 & $600,00 \%$ & 0,00 & 0,01 & 0,03 & 0,27 \\
\hline Teapri & 44,50 & 42,15 & $-5,28 \%$ & 27,50 & 23,00 & 63,70 & 65,30 \\
\hline Teasec & 21,33 & 24,19 & $13,41 \%$ & 13,30 & 14,43 & 33,00 & 45,57 \\
\hline Salarp & 5688,46 & 5511,60 & $-3,11 \%$ & 1168,65 & 943,00 & 11248,00 & 10796,00 \\
\hline Drop & 44,49 & 33,66 & $-24,34 \%$ & 4,00 & 0,00 & 92,00 & 92,00 \\
\hline Deprim & 19,14 & 12,84 & $-32,92 \%$ & 7,60 & 3,00 & 52,05 & 32,20 \\
\hline Per Cap & 1413,77 & 2056,17 & $45,44 \%$ & 481,48 & 630,08 & 4304,64 & 6555,60 \\
\hline
\end{tabular}

Table 4.

${ }^{8} \hat{h}$, average number of years of schooling of the population aged 25 years or older; $\hat{h}^{\text {pri }}$, average number of years of schooling at the primary level; $\hat{h}^{\text {sec }}$, average number of years of schooling at the secondary level; $\hat{h}^{\text {High }}$, average number of years of schooling at the higher education level; Teapri, number of students per teacher at the primary level; Teasec, number of students per teacher at the secondary level; Drop, primary level dropout rate; Salarp, average real wage of a primary school teacher; Deprim, the impact on the per capita GDP of public expenses per student at the primary level. 


\begin{tabular}{|c|c|c|c|c|c|c|c|}
\hline \multirow{2}{*}{ Variables ${ }^{8}$} & \multicolumn{3}{|c|}{ Mean } & \multicolumn{2}{|c|}{ Minimum } & \multicolumn{2}{|c|}{ Maximum } \\
\hline & 1970 & 2000 & Ecart & 1970 & 2000 & 1970 & 2000 \\
\hline$G D P$ & & & & & & & \\
\hline $\begin{array}{l}\text { Population } \\
\text { (in } \\
\text { thousands) }\end{array}$ & 5779,58 & 12151,16 & $110,24 \%$ & 484,58 & 1221,44 & 33574,03 & 67600,17 \\
\hline
\end{tabular}

\section{Empirical Results}

As explained in the methodology section, when considering human capital we distinguish between the case in which diminishing returns are integrated and that in which the qualitative variables of human capital are taken into consideration. Thus, in view of the the hypothesis made to consider human capital, we have distinguished four models:

1. Model 0: Solow growth model without considering the variable of human capital

(12) $\ln y_{i}^{*}=a+\beta_{1} \ln \left(s_{k i}\right)+\beta_{2} \ln \left(n_{i}+g+\delta\right)+\varepsilon_{i t}$

Here, the impact of variables such as saving rate and demographic growth rate on the level of per capita GDP is assessed.

2. Model 1: Model with introduction of the variable of human capital $\left(h_{i}^{M}\right)$ according to the Mincerian approach to human capital

(13) $\ln y_{i}^{*}=a+\beta_{1} \ln \left(s_{k i}\right)+\beta_{2} \ln \left(h_{i}^{M}\right)+\beta_{3} \ln \left(n_{i}+g+\delta\right)+\varepsilon_{i t}$

3. Model 2: Model with introduction of the variable of human capital according to the PCA approach to human capital $\left(h_{i}^{P C A}\right)$ and the average number of years of schooling $\hat{h}_{i}$

(14) $\ln y_{i}^{*}=a+\beta_{1} \ln \left(s_{k i}\right)+\beta_{2} \ln \left(h_{i}^{P C A}\right)+\beta_{3} \ln \left(\hat{h}_{i}\right)+\beta_{4} \ln \left(n_{i}+g+\delta\right)+\varepsilon_{i t}$

4. Model 3: Model with introduction of the variable of human capital according to the PCA approach to human capital $\left(h_{i}^{P C A}\right)$ and decomposition into educational level $\hat{h}_{i}^{\text {lev }}$ The average number of years of schooling has been decomposed into years of schooling at the primary, secondary, and higher levels.

(15) $\ln y_{i}^{*}=a+\beta_{1} \ln \left(s_{k i}\right)+\beta_{2} \ln \left(h_{i}^{\text {PCA }}\right)+\beta_{3} \ln \left(\hat{h}_{i}^{\text {Pri }}\right)+\beta_{4} \ln \left(\hat{h}_{i}^{\text {Sec }}\right)+\beta_{5} \ln \left(\hat{h}_{i}^{\text {High }}\right)+$ $\beta_{6} \ln \left(n_{i}+g+\delta\right)+\varepsilon_{i t}$ 
It should be specified that in estimating these four models, we have proceeded to the usual econometric tests in order to use the estimation method best adapted to our analysis. ${ }^{9}$

\subsection{Estimate of the Productivity Equation}

The estimate of Equation (7) assumes that countries are in a steady state and allows for the measurement of the contribution of different explicative variables (capital investment rate, demographic growth rate, and stock of human capital) on the level of per capita GDP. In Table 2, we present the results obtained for the four models. We first analyse those derived from the estimate of Model 0 (Equation Erreur! Source du renvoi introuvable.)). The two principal explicative variables of the level of per capita GDP (saving rate and demographic growth rate) are positive and statistically significant. However, in accordance with the predictions of the Solow model, we expected for the coefficient associated with the demographic growth rate to be negative. This already intimates that the Solow model does not allow for a satisfactory explanation of the data on our sample based on 22 African countries. When it comes to saving, we again find the standard positive relation in the Solow model.

We now integrate different human capital variables into our regressions, in order to evaluate the effect on the level of per capita GDP. The results obtained from the estimates of Model 1 assume that the stock of human capital is evaluated while taking into consideration diminishing returns as described above (Equation Erreur ! Source du renvoi introuvable.)). The table shows lower levels of coefficients of the investment rate and of the demographic growth rate; these variables lose their significance at $5 \%$, however, with the integration of our human capital variable $\left(h^{M}\right)$ into the regression. The Mincerian variable of human capital has a positive and statistically significant coefficient, which expresses that human capital evaluated with diminishing returns explains well the level of equilibrium of the per capita GDP for our sample of African countries-its contribution is in fact here evaluated at approximately $61 \%$. We thus find once again the positive role of human capital when it is specified in the Mincerian form, as in the results of Wössman (2000), which confirms the essential role of education in developing countries in general and Africa in particular.

Table 2 also presents the estimate of Model 2 (Equation (14)) and thus of the level of equilibrium of the per capita GDP according to the traditional variables (investment rate and

\footnotetext{
${ }^{9}$ The results of the tests can be found in the appendix (cf. Erreur ! Source du renvoi introuvable.).
} 
demographic growth rate) and of stock of human capital, where it is represented by two variables, one of which is quantitative (number of years of schooling) and the other qualitative (composite indicator of human capital described above). The results obtained show that all the variables of human capital have statistically significant coefficients, with a stronger impact of the quantitative variable of human capital ( $42 \%$ versus $10 \%$ for the qualitative variable). The demographic growth rate coefficient again becomes significant at $5 \%$, but always positive, contrary to the predictions of the Solow model.

We next decomposed the quantitative variable of human capital in order to estimate the impact on the level of per capita GDP of the different numbers of years of schooling at the primary, secondary, and higher levels (Model 3).

Table 2: Estimate of the productivity equation

\begin{tabular}{|c|c|c|c|c|}
\hline Variables & Model 0 & Model $1^{10}$ & Model $2^{11}$ & Model $3^{12}$ \\
\hline $\operatorname{Ln}\left(s_{k}\right)$ & $\begin{array}{c}0.185^{* * *} \\
(0.036)\end{array}$ & $\begin{array}{c}0.022 \\
(0.035)\end{array}$ & $\begin{array}{c}0.049 \\
(0.045)\end{array}$ & $\begin{array}{c}0.159 * * * \\
(0.042)\end{array}$ \\
\hline $\operatorname{Ln}\left(n_{i}\right)$ & $\begin{array}{c}0.453 * * * \\
(0.1046)\end{array}$ & $\begin{array}{c}0.080 * * \\
(0.053)\end{array}$ & $\begin{array}{c}0.239 * * * \\
(0.119)\end{array}$ & $\begin{array}{c}0.066 \\
(0.081)\end{array}$ \\
\hline $\operatorname{Ln}\left(h^{M}\right)$ & & $\begin{array}{c}0.608^{* * *} \\
(0.154)\end{array}$ & & \\
\hline $\operatorname{Ln}\left(h^{P C A}\right)^{13}$ & & & $\begin{array}{c}0.098 * * * \\
(0.027)\end{array}$ & $\begin{array}{c}0.050 * * * \\
(0.011)\end{array}$ \\
\hline $\operatorname{Ln}(\hat{h})$ & & & $\begin{array}{c}0.420 * * * \\
(0.037)\end{array}$ & \\
\hline $\operatorname{Ln}\left(\hat{h}^{\text {Prim }}\right)$ & & & & $\begin{array}{l}-0.068 \\
(0.122)\end{array}$ \\
\hline $\operatorname{Ln}\left(\hat{h}^{S e c}\right)$ & & & & $\begin{array}{c}0.233^{* * *} \\
(0.065)\end{array}$ \\
\hline $\operatorname{Ln}\left(\hat{h}^{H i g h}\right)$ & & & & $\begin{array}{c}0.192^{* * *} \\
(0.035)\end{array}$ \\
\hline Constant & $\begin{array}{c}9.186 * * * \\
(0.219)\end{array}$ & $\begin{array}{c}7.832 * * * \\
(0.16)\end{array}$ & $\begin{array}{c}8.159 * * * \\
(0.26)\end{array}$ & $\begin{array}{c}9.468 * * * \\
(0.309)\end{array}$ \\
\hline
\end{tabular}

Values in parenthesis are standard errors.

$* * *$ Coefficients significant at $5 \%$

** Coefficients significant at $10 \%$

The purpose of this decomposition is to assess the contribution of different levels of study on the level of per capita GDP. The number of years of schooling at the secondary and higher levels has a positive and significant impact on the level of per capita GDP, while the variable of the number of years of schooling at the primary level is not significant. Thus, an

\footnotetext{
${ }^{10} h^{M}$ represents human capital stock estimated with the Mincerian approach.

${ }^{11} \hat{h}$ represents the average years of school for the population over 25 years old.

${ }^{12} \hat{h}^{\text {Prim }}$ represents the average year of primary school, $\hat{h}^{\text {Sec }}$ secondary and $\hat{h}^{\text {Sup }}$ higher levels.

${ }^{13} \hat{h}^{P C A}$ represents human capital stock estimated with the PCA method.
} 
additional year of studies at the secondary and higher levels may have a positive and significant impact on the level of per capita GDP, and thus on growth for our sample, while the number of years of studies at the primary level may not be sufficient to influence the levels of per capita GDP. The qualitative variable of human capital always remains positive and significant, although with a weaker impact (approximately 5\%) on the level of equilibrium of per capita GDP, according to the decomposition of the quantitative variable of human capital.

Studying these results indicates that our data on 22 African countries over the period 1970 to 2000 does not allow for a reproduction of the Solow model. However, the different approaches used to take human capital into consideration (PCA and Mincerian approach) show a significant and positive impact of human capital on per capita GDP, which becomes even greater with the Mincerian approach. This demonstrates that considering these diminishing returns in the evaluation of human capital is important and allows one to arrive at its positive impact in the process of economic growth.

With the PCA approach we have observed that besides the average number of years of schooling, the investments made in educational system quality are determinant in explaining levels of per capita GDP. However, the impact of the qualitative variable of human capital is weaker than the impact of the quantitative variable. Thus, it may be that the more time individuals spend in school, the more they acquire a stock of human capital likely to influence the level of per capita GDP, contrary to what Pritchett (2001) had suggested; but the level of educational system quality is not high enough to properly influence the level of per capita GDP for our sample of developing countries. The decomposition of the average number of years of schooling at the primary, secondary, and higher levels has allowed us to show that an additional year at the secondary or higher levels could have a positive impact on the level of per capita income in Africa.

\subsection{Estimate of the Convergence Equation}

We have thus far assumed that the countries were in their steady state or, more generally, that the differences separating them from the steady state were random. This hypothesis can however be questioned. Indeed, it is probable that the data are influenced by a non steady state dynamic, notably due to the slowness of convergence toward the steady state itself. Estimates have been made in order to assess the convergence process in our sample of African countries. We explain the difference in growth between two periods by the initial per capita GDP $\left(y_{i, t-1}\right)$, the demographic growth rate, the physical investment 
rate, and also the stock of human capital. Table 3 allows for an assessment of the convergence process for each of our four estimated models.

Let us first observe what takes place when human capital is not considered in the convergence equation (Equation (9)). The plus sign of the initial per capita GDP coefficient confirms the existence of a per capita GDP convergence process in our sample of African countries with a convergence speed of $0.027 \%$.

Table 3: Estimate of the convergence equation

\begin{tabular}{|c|c|c|c|c|}
\hline Variables & Model 0 & Model $1^{14}$ & Model $2^{15}$ & Model $3^{16}$ \\
\hline $\operatorname{Ln}\left(s_{k}\right)$ & $\begin{array}{c}0.072 * * * \\
(0.072)\end{array}$ & $\begin{array}{c}0.073 * * * \\
(0.015)\end{array}$ & $\begin{array}{c}0.070 * * * \\
(0.014)\end{array}$ & $\begin{array}{c}0.066 * * * \\
(0.015)\end{array}$ \\
\hline $\operatorname{Ln}\left(n_{i}\right)$ & $\begin{array}{l}-0.034 \\
(0.033)\end{array}$ & $\begin{array}{l}-0.057 \\
(0.033)\end{array}$ & $\begin{array}{l}-0.047 \\
(0.031)\end{array}$ & $\begin{array}{l}-0.038 \\
(0.034)\end{array}$ \\
\hline $\operatorname{Ln}\left(y_{i . t-1}\right)$ & $\begin{array}{c}0.998 * * * \\
(0.011)\end{array}$ & $\begin{array}{c}0.990 * * * \\
(0.013)\end{array}$ & $\begin{array}{c}0.982 * * * \\
(0.012)\end{array}$ & \\
\hline $\operatorname{Ln}\left(h^{M}\right)$ & & $\begin{array}{l}0.0534 \\
(0.044)\end{array}$ & & \\
\hline $\operatorname{Ln}\left(h^{P C A}\right)^{17}$ & & & $\begin{array}{c}0.012^{* * *} \\
(0.004)\end{array}$ & $\begin{array}{c}0.011^{* * *} \\
(0.005)\end{array}$ \\
\hline $\operatorname{Ln}(\hat{h})$ & & & $\begin{array}{c}0.041 * * * \\
(0.015)\end{array}$ & \\
\hline $\operatorname{Ln}\left(\hat{h}^{\text {Prim }}\right)$ & & & & $\begin{array}{c}0.049 * * * \\
(0.019)\end{array}$ \\
\hline $\operatorname{Ln}\left(\hat{h}^{S e c}\right)$ & & & & $\begin{array}{l}-0.001 \\
(0.019)\end{array}$ \\
\hline $\operatorname{Ln}\left(\hat{h}^{\text {High }}\right)$ & & & & $\begin{array}{l}-0.013 \\
(0.013)\end{array}$ \\
\hline Constant & $\begin{array}{c}0.165 \\
(0.138)\end{array}$ & $\begin{array}{c}0.196 \\
(0.137)\end{array}$ & $\begin{array}{c}0.245^{* *} \\
(0.133)\end{array}$ & $\begin{array}{c}0.071 \\
(0.203)\end{array}$ \\
\hline $\begin{array}{c}\text { convergence } \\
\text { speed, } \lambda\end{array}$ & 0.027 & 0.201 & 0.367 & 0.034 \\
\hline
\end{tabular}

Values in parenthesis are standard errors.

*** Coefficients significant at $5 \%$

** Coefficients significant at $10 \%$

Next, we introduced the variables of human capital in order to evaluate their impact in this economic convergence process. The first estimated model corresponds to Model 1 , in which the impact of human capital in the growth process is considered using the Mincerian variable of human capital. The positive impact of the variable of human capital $h^{M}$ which we had previously persists, but is only significant at $20 \%$. Moreover, the plus sign of the variable of per capita GDP and the fact that the coefficient is statistically significant both confirm the

\footnotetext{
${ }^{14} h^{M}$ represents human capital stock estimated with the Mincerian approach.

${ }^{15} \hat{h}$ represents the average years of school for the population over 25 years old.

${ }^{16} \hat{h}^{\text {Prim }}$ represents the average year of primary school, $\hat{h}^{\text {Sec }}$ secondary and $\hat{h}^{\text {Sup }}$ higher levels.

${ }^{17} h^{P C A}$ represents human capital stock estimated with the PCA method.
} 
existence of a convergence process in the sample of 22 African countries. By using this variable to assess the level of the stock of human capital, the convergence speed of these economies now rises to $0.201 \%$, a rate nearly 7.5 times greater than when human capital is not taken into consideration in the model.

We have also assessed the impact of the other variables of human capital in the economic convergence process. The results obtained from Model 2 show a positive and significant impact of the qualitative variable of human capital acquired using the PCA and of the quantitative variable via the number of years of schooling of human capital $(\hat{h})$ with, in our case, a stronger impact of the number of years of schooling in the convergence process. Indeed, the impact of $\left(h^{P C A}\right)$ is $1.2 \%$ while that of $(\hat{h})$ is $4.1 \%$ in the convergence process. By using two of these variables to assess the level of the stock of human capital, the speed of convergence of these economies now rises to $0.37 \%$, that is to say 13.7 times faster than when human capital is not considered (Model 0). In addition, the distinction between quantitative and qualitative human capital also seems to accelerate the convergence process, since the speed almost doubled in relation to the equation with the Mincerian form of human capital.

Finally, as with the study of per capita GDP, we have decomposed the number of years of schooling according to those at the primary, secondary, and higher levels, to assess their respective impact on the convergence process. Contrary to what we obtained previously at the steady state, we observe that the role of primary education becomes important in the convergence process. Indeed, we observe that only the variables of the number of years of schooling at the primary level $\left(\hat{h}^{p r i}\right)$ and the qualitative composite indicator of human capital $\left(h^{P C A}\right)$ are significant and positive; the other variables are not significant, contrary to what had been obtained in the estimate of the productivity equation, where only the primary level was not significant. The contribution of the number of years of schooling at the primary level here rises to approximately $5 \%$ in the convergence process. This could indicate that the countries in our sample are more similar in terms of primary level education, a fact which may contribute to bringing them together in a convergence process. The countries may concentrate more on primary education than on secondary and higher education; for these last levels, there may thus be greater divergence between countries. By using the results of Vandenbussche, Aghion and Meghir (2006), in which the closer a country is to its technological frontier the more it requires qualified labour, it could be said that our sample of countries is still far from this technological frontier; hence the importance of primary level 
education in Africa, since it offers less qualified human capital than other levels of study. In this last model, we observe a significant slowdown in the speed of convergence reaching barely $0.034 \%$ faster than when human capital is not integrated into the model (Model 0 ).

Generally speaking, our data confirm the existence of a convergence process of the per capita GDP for our sample of 22 African countries, with a convergence speed varying according to the indicator used for the stock of human capital. This result is consistent with those of a number of studies carried out using data on African countries such as that of Ndiaye (2006) that shows the existence of a convergence process in the WAEMU zone, even if it is relatively weak (1.71\% between 1980 and 2000). Similar results can be found in the work of Dramani (2007), who studies convergence in the economies of developing countries, namely in Africa in the WAEMU and CEMAC zones, using the convergence theory inspired by endogenous growth models. The author uses the similarities in terms of production factors and of natural advantages, which enable him to reveal the presence of a convergence process. In our case, we also highlight the importance of distinguishing the form of human capital in an analysis of convergence.

\section{Conclusion}

In this work, we have evaluated the contribution of human capital in the processes of economic growth and convergence in a sample of 22 African countries for the period 1970 to 2000. We have more specifically integrated the qualitative aspects of human capital in addition to the quantitative dimension usually chosen. We have also assumed diminishing returns of human capital by basing our work on a neoclassical model based on the approach put forward by Islam (1995). In order to integrate the qualitative aspects of human capital, we have constructed a composite indicator thanks to a principal component analysis using several indicators related to educational system inputs. With regard to the consideration of diminishing returns of human capital, we have adopted the specification proposed by Mincer (1974). The results show that considering the qualitative aspects and diminishing returns of human capital enabled the discovery of a positive and significant relation concerning the process of economic growth. The data also reveal a conditional convergence process (although slow) for the sample of African countries over the period 1970 to 2000.

This study aims to enrich the debate on the relation between human capital and growth through its study of this relation for a sample of African countries using panel data, and notably by using a new type of indicator of human capital. This new principal component 
analysis based proxy allows for a greater acknowledgment of human capital and contributes to an enhanced evaluation of the qualitative aspects of human capital, especially in developing countries for which the lack of data is a considerable problem. As we have demonstrated, its role proves important in the study of both economic growth and convergence of African countries.

In addition to this work, it will nonetheless be interesting to pursue our analysis by adding the heterogeneity of studied countries, for instance according to criteria such as the distinction between Francophone and Anglophone countries or simply using geographic differentiation-and to observe whether our results in terms of growth and convergence are confirmed.

\section{Bibliography}

Aghion, P. and Howitt, P., (1998), Endogenous Growth Theory, The MIT Press, Cambridge, MA.

Altinok, N., (2006), "Capital humain et croissance : I'apport des enquêtes internationales sur les acquis des élèves", Economie publique, Vol. 18-19, №1-2, pages 177-209.

Azariadis, C. and Drazen, A., (1990), "Threshold Externalities in Economic Development," The Quarterly Journal of Economics, Vol. 105, №2, pages 501-526.

Barro, R., (1991), "Economic Growth in a Cross Section of Countries", The Quarterly Journal of Economics, Vol. $106, \mathrm{~N}^{\circ} 2$, pages $407-443$.

Barro, R., (1997), Macroeconomics, The MIT Press, Cambridge, MA.

Barro, R., (1999)," Notes on Growth Accounting," Journal of Economic Growth, Vol. 4, №2, pages 119-137.

Barro, R., (2001), "Human Capital and Growth," American Economic Review, Vol. 91, №2, pages 12-17.

Barro, R., and Lee, J., (1993), "International Comparisons of Educational Attainment". Journal of Monetary Economics, Vol. 32, $\mathrm{N}^{\circ} 3$ pages 363-394.

Barro, R. and Lee, J., (1996) "International Measures of Schooling Years and Schooling Quality," American Economic Review, Vol. 86, N²2, pages 218-223.

Barro, R. and Lee, J., (2001), "International Data on Educational Attainment: Updates and Implications", Oxford Economic Papers, Vol. 53, N3, pages 541-563.

Barro, R. and Lee, J., (2001), "Schooling Quality In A Cross-Section Of Countries", Economica, Vol.68, N²71, pages 465-488.

Barro, R. and Sala-i-Martin, X., (1992), "Convergence", The Journal of Political Economy, Vol.100, $\mathrm{N}^{\circ} 2$, pages 223-251.

Barro, R., and Sala-i-Martin, X., (1995), "Technological Diffusion, Convergence, and Growth," NBER Working Papers $N^{\circ} 5151$, National Bureau of Economic Research, Inc.

Becker, G., (1964), Human Capital: a Theoretical Empirical Analysis with Special Reference to Education, Columbia University Press, New York, NY.

Becker, G., (1974), "A Theory of Social Interactions", The Journal of Political Economy, Vol.82, N 6 , pages $1063-1093$. 
Benhabib, J. and Spiegel M., (1994), "The Role of Human Capital in Economic Development: Evidence from Aggregate Cross-country Data", Journal of Monetary Economics, Vol.34, $\mathrm{N}^{\circ} 2$, pages $143-173$.

Bosca, J., de la Fuente A. and Domenech R., (2000), "Schooling Data: Some Problems and Implications for Growth Regressions", unpublished, Instituto de Analisis Economico CSIC.

Caselli, F., Esquivel, G. and Fernando L., (1996), "Reopening the Convergence Debate: a New Look at Cross-country Growth Empirics", Journal of Economic Growth, Vol.1, N³, pages 363-389.

Créel, J. and Poilon G., (2006), "Is Public Capital Productive in Europe?", Document de travail de I'OFCE, Observatoire Français des Conjonctures économiques, Centre de recherche en économie de Sciences Po, №2006-10.

Denison, E., (1967), "Why Growth Rates Differ: Postwar Experience in Nine Western Countries", The Brookings Institution, Washington D. C.

Dessus, S., (2000), "Capital humain et croissance: le rôle retrouvé du système éducatif", Économie publique, Vol. 2, N6, pages 95-115.

Dramani, L., (2007), "Convergence and Economic Integration in Africa: Case of CFA countries", MPRA Paper $\mathrm{N}^{\circ} .3033$.

Hanushek, E. and Kimko, D., (2000), "Schooling, Labor-Force Quality, and the Growth of Nations", American Economic Review, Vol.90, N5, pages 1184-1208.

Heston, A. Summers, R. and Aten, B., (2006), "Penn World Table Version 6.2", Center for International Comparisons of Production, Income and Prices de l'Université de Pennsylvanie

Islam, N., (1995), "Growth Empirics : A Panel Data Approach". The Quaterly Journal of economics, Vol. 110, $\mathrm{N}^{\circ} 4$, pages 1127-1170.

Jorgenson, D., (1995), "Post War Economic Growth", MIT Press, Cambridge, MA.

Krueger, A. and Lindahl, M., (2001), "Education and Growth: Why and for Whom? " Princeton Working Paper $\mathrm{N}^{\circ} 429$, Princeton University.

Levine, R. and Renelt, D., (1992), "A Sensitivity Analysis of Cross-Country Growth Regressions". American Economic Review, Vol.82 N4, pages 942-963.

Lucas, R., (1988), "On the Mecanics of Economic Development". Journal of Monetary Economics, Vol. 22, $\mathrm{N}^{\circ} 1$, pages 3-42.

Mankiw, G., Romer, D. and Weil, D. (1992) "A Contribution to the Empirics of Economic Growth," The Quarterly Journal of Economics, Vol. 107, N², pages 407-437.

Mincer, J., (1958), "Investment in Human Capital and Personal Income Distribution", The Journal of Political Economy, Vol. 66, N4, pages 281-302.

Mincer, J., (1974), "Schooling, Experience, and Earnings", Columbia University Press, New York, NY

Ndiaye, O., (2006), "UEMOA : une intégration économique à deux vitesses à travers des clubs de Convergence" 7èmes journées scientifiques du réseau Analyse Économique et Développement de l'AUF.

Nelson, R. and Phelps, E., (1966), "Investment in Humans, Technological Diffusion and Economic Growth", American Economic Review, Vol. 56, N¹/2, pages 69-75.

Pritchett, L., (2001), “Where Has All the Education Gone?" World Bank Economic Review, Vol. 15, $\mathrm{N}^{\circ} 3$, pages 367-391.

Psacharopoulos, G., (1994), "Returns to Investment in Education: A Global Update", World Development, Vol.22, N9, pages 1325-1343.

Psacharopoulos, G. and Patrinos H., (2002), "Returns to Investment in Education: A further Update", World Bank Policy Research Working Paper N²881. 
Romer, P., (1986), "Increasing Returns and Long-run Growth", The Journal of Political Economy, Vol.94, N5, pages 1002-1037.

Romer, P., (1990), "Endogeneous Technical Change", The Journal of Political Economy, Vol.98, N S5, pages 71-102.

Schultz, T., (1961), "Investment in human capital", American Economic Review, Vol.51, N¹, pages 1-17.

Smith A., (1776), La Richesse des nations (1re édition), trad. de Germain Garnier revue par Adolphe Blanqui (1881), 2 tomes, Gallimard, Paris.

Solow, R., (1956), "A Contribution to the Theory of Economic Growth", Quarterly Journal of Economics, Vol.70, N 1 , pages 65-94.

Vandenbussche, J., Aghion, P. and Meghir, C., (2006), "Growth, Distance to Frontier and Composition of Human Capital", Journal of Economic Growth, Vol.11, N22, pages 97-127.

Volle M., (1997), “Analyse des données", Economica, $4{ }^{\text {ème }}$ édition, France

Wössman, L., (2000), "Specifying Human Capital: a Review, some Extensions and Development Effects", Kiel Institute of World Economics, Working Paper Nº1007.

\section{APPENDIX}

\subsection{List of countries}

\begin{tabular}{cccc} 
& Pays & & Pays \\
\hline 1 & Algeria & 12 & Malawi \\
\hline 2 & Benin & 13 & Mali \\
\hline 3 & Botswana & 14 & Niger \\
\hline 4 & Cameroun & 15 & Rwanda \\
\hline 5 & Central Africa & 16 & Senegal \\
\hline & & & Sierra \\
\hline 6 & Congo & 17 & Leone \\
\hline 7 & Egypt & 18 & Tanzania \\
\hline 8 & Gambia & 19 & Togo \\
\hline 9 & Ghana & 20 & Tunisia \\
\hline 10 & Guinea-Bissau & 21 & Zambia \\
\hline 11 & Lesotho & 22 & Zimbabwe
\end{tabular}

\subsection{Descriptive Statistics by Country}

Table 4: Means for variables or interest over 30 years $(1970-2000)^{18}$

\begin{tabular}{|c|c|c|c|c|c|c|c|}
\hline Countries & $\hat{h}$ & $\hat{h}_{\text {Pri }}$ & $\hat{h}_{\text {Sec }}$ & $\hat{h}_{\text {High }}$ & Teapri & Teasec \\
\hline Algeria & 3.45 & 2.36 & 1.02 & 0.08 & 32.47 & 22.26 \\
\hline Benin & 1.44 & 1.14 & 0.29 & 0.02 & 44.64 & 30.80 \\
\hline
\end{tabular}

${ }^{18} \hat{h}$, average number of years of schooling of the population aged 25 years or older; $\hat{h}^{\text {pri }}$, average number of years of schooling at the primary level; $\hat{h}^{\text {sec }}$, average number of years of schooling at the secondary level; $\hat{h}^{\text {High }}$, average number of years of schooling at the higher education level; Teapri, number of students per teacher at the primary level; Teasec, number of students per teacher at the secondary level; Drop, primary level dropout rate; Salarp, average real wage of a primary school teacher; Deprim, the impact on the per capita GDP of public expenses per student at the primary level. 


\begin{tabular}{|c|c|c|c|c|c|c|}
\hline Countries & $\hat{h}$ & $\hat{h}_{\text {Pri }}$ & \multicolumn{1}{c}{$\hat{h}_{\text {Sec }}$} & $\hat{h}_{\text {High }}$ & Teapri & Teasec \\
\hline Botswana & 4.06 & 3.34 & 0.67 & 0.05 & 31.11 & 17.53 \\
\hline Cameroun & 2.74 & 2.14 & 0.58 & 0.03 & 50.16 & 26.74 \\
\hline Central Africa & 1.71 & 1.29 & 0.40 & 0.02 & 69.16 & 44.58 \\
\hline Congo & 5.10 & 3.19 & 1.81 & 0.07 & 61.89 & 34.78 \\
\hline Egypt & 3.70 & 2.34 & 1.20 & 0.13 & 30.24 & 22.19 \\
\hline Gambia & 1.47 & 0.99 & 0.44 & 0.01 & 28.45 & 21.38 \\
\hline Ghana & 3.55 & 2.31 & 1.22 & 0.02 & 29.62 & 19.92 \\
\hline Guinea-Bissau & 0.60 & 0.50 & 0.08 & 0.00 & 33.34 & 12.67 \\
\hline Lesotho & 3.86 & 3.52 & 0.33 & 0.02 & 50.33 & 21.11 \\
\hline Malawi & 2.65 & 2.50 & 0.15 & 0.01 & 58.76 & 24.91 \\
\hline Mali & 0.60 & 0.49 & 0.10 & 0.01 & 48.94 & 17.28 \\
\hline Niger & 0.68 & 0.55 & 0.12 & 0.01 & 39.79 & 25.43 \\
\hline Rwanda & 1.89 & 1.72 & 0.16 & 0.01 & 56.10 & 16.74 \\
\hline Senegal & 2.21 & 1.78 & 0.39 & 0.04 & 49.40 & 27.79 \\
\hline Sierra Leone & 1.81 & 1.32 & 0.47 & 0.02 & 32.78 & 22.42 \\
\hline Tanzania & 2.74 & 2.56 & 0.14 & 0.04 & 40.63 & 19.36 \\
\hline Togo & 2.35 & 1.73 & 0.59 & 0.04 & 52.34 & 29.33 \\
\hline Tunisia & 3.36 & 2.36 & 0.91 & 0.09 & 33.31 & 20.92 \\
\hline Zambia & 4.13 & 3.53 & 0.57 & 0.03 & 43.98 & 22.82 \\
\hline Zimbabwe & 3.50 & 2.54 & 0.90 & 0.06 & 39.44 & 23.54 \\
\hline
\end{tabular}

\begin{tabular}{|c|c|c|c|c|c|}
\hline Countries & Salarp (in \$) & Drop (in \%) & Deprim (en \%) & Per Cap GDP (\$) & Population (in Thousands) \\
\hline Algeria & 10475.57 & 17.61 & 12.90 & 5032.26 & 21291.00 \\
\hline Benin & 7847.96 & 64.00 & 16.58 & 1139.37 & 4005.45 \\
\hline Botswana & 5362.07 & 23.05 & 10.11 & 3680.52 & 1040.91 \\
\hline Cameroun & 3226.89 & 30.36 & 6.65 & 2405.11 & 9936.79 \\
\hline Central Africa & 7160.71 & 54.72 & 17.92 & 991.65 & 2489.32 \\
\hline Congo & 8334.21 & 34.41 & 7.55 & 2003.99 & 1864.03 \\
\hline Egypt & 6447.93 & 9.00 & 14.70 & 2840.03 & 48383.28 \\
\hline Gambia & 2318.21 & 4.00 & 15.39 & 898.94 & 805.84 \\
\hline Ghana & 1465.50 & 20.70 & 6.32 & 1148.35 & 13056.48 \\
\hline $\begin{array}{l}\text { Guinea- } \\
\text { Bissau }\end{array}$ & 3132.21 & 92.00 & 29.40 & 642.84 & 874.36 \\
\hline Lesotho & 5509.79 & 56.15 & 16.77 & 1163.07 & 1450.88 \\
\hline Malawi & 1679.31 & 61.76 & 9.37 & 675.12 & 7190.74 \\
\hline Mali & 7204.96 & 53.89 & 37.57 & 812.71 & 7397.95 \\
\hline Niger & 6957.50 & 22.50 & 32.04 & 1020.76 & 6485.99 \\
\hline Rwanda & 5173.79 & 48.76 & 13.53 & 1063.89 & 5542.90 \\
\hline Senegal & 9578.43 & 17.18 & 21.69 & 1444.92 & 6396.13 \\
\hline Sierra Leone & 1952.38 & 64.00 & 6.48 & 1191.37 & 3668.50 \\
\hline Tanzania & 1532.36 & 24.59 & 13.05 & 568.59 & 21736.82 \\
\hline Togo & 2850.00 & 39.43 & 10.37 & 1090.29 & 3089.87 \\
\hline Tunisia & 10389.14 & 25.02 & 12.83 & 4489.87 & 7077.58 \\
\hline Zambia & 2767.18 & 18.65 & 6.99 & 1195.70 & 6561.11 \\
\hline Zimbabwe & 8587.57 & 18.86 & 17.25 & 3181.60 & 8363.52 \\
\hline
\end{tabular}


7.3. Results of the Principal Component Analysis (PCA)

Table 5 : Total Variance Explained

\begin{tabular}{|c|c|c|c|c|c|c|c|c|c|}
\hline \multirow{2}{*}{ Components } & \multicolumn{3}{|c|}{ Initial Eigenvalues } & \multicolumn{3}{|c|}{$\begin{array}{l}\text { Extraction Sums of Squared } \\
\text { Loadings }\end{array}$} & \multicolumn{3}{|c|}{$\begin{array}{l}\text { Extraction Sums of Squared } \\
\text { Loadings for rotation }\end{array}$} \\
\hline & Total & $\begin{array}{c}\% \text { of } \\
\text { Variance }\end{array}$ & $\begin{array}{c}\text { Cumulative } \\
\%\end{array}$ & Total & $\begin{array}{c}\% \text { of } \\
\text { Variance }\end{array}$ & $\begin{array}{c}\text { Cumulative } \\
\%\end{array}$ & Total & $\begin{array}{c}\% \text { of } \\
\text { Variance }\end{array}$ & $\begin{array}{c}\text { Cumulative } \\
\%\end{array}$ \\
\hline 1 & 1.65 & 27.47 & 27.47 & 1.65 & 27.47 & 27.47 & 1.63 & 27.19 & 27.19 \\
\hline 2 & 1.32 & 22.07 & 49.54 & 1.32 & 22.07 & 49.54 & 1.34 & 22.35 & 49.54 \\
\hline 3 & 1.14 & 19.00 & 68.54 & & & & & & \\
\hline 4 & 0.96 & 16.04 & 84.59 & & & & & & \\
\hline 5 & 0.55 & 9.09 & 93.68 & & & & & & \\
\hline 6 & 0.38 & 6.33 & 100.00 & & & & & & \\
\hline
\end{tabular}

Table 6 : Component Matrix

\begin{tabular}{|c|c|c|}
\hline \multirow{2}{*}{ Variables } & \multicolumn{2}{c|}{ Components } \\
& Components & Variables \\
\hline DEPRIM & -0.179 & 0.630 \\
\hline SCHDAY & 0.425 & -0.136 \\
\hline SALARP & -0.288 & 0.809 \\
\hline DROP & 0.473 & -0.066 \\
\hline TEAPRI & 0.875 & 0.174 \\
\hline TEASEC & 0.602 & 0.469 \\
\hline
\end{tabular}

7.4. Test Results

7.4.1. Tests on the Productivity Equation

\begin{tabular}{|c|c|c|c|c|}
\hline Test & Model 0 & Model 1 & Model 2 & Model 3 \\
\hline & "Without KH" & $\begin{array}{c}\text { "Mincerian } \\
\text { approach to KH" }\end{array}$ & "PCA approach" & $\begin{array}{l}\text { "PCA approach } \\
\text { with } \\
\text { decomposition } \\
\text { of } \mathrm{KH}^{\text {" }}\end{array}$ \\
\hline \multirow{2}{*}{ Presence of individual effects } & $F(21,130)=67,56$ & $F(21,129)=67,39$ & $F(21,128)=59,23$ & $F(21,126)=44,23$ \\
\hline & 0,00 & 0,00 & 0,00 & 0,00 \\
\hline \multirow{2}{*}{$\begin{array}{c}\text { Fixed effects vs. random } \\
\text { effects } \\
\text { (Hausman Test) }\end{array}$} & Chi2(2) $=49,66$ & Chi2(3)=4,59 & Chi2 $(4)=6,36$ & Chi2(6) $=-377,56$ \\
\hline & 0,00 & 0,2047 & 0,1727 & \\
\hline \multirow{2}{*}{$\begin{array}{l}\text { Heteroscedasticity } \\
\text { (Breusch-Pagan Test) }\end{array}$} & $\mathrm{LM}=153,99$ & $L M=153,97$ & $L M=153,98$ & $L M=153,97$ \\
\hline & 0,00 & 0,00 & 0,00 & 0,00 \\
\hline \multirow{2}{*}{$\begin{array}{c}\text { Intra-individual } \\
\text { heteroscedasticity }\end{array}$} & $\begin{array}{c}\text { Chi2(22) }=9497,2 \\
8\end{array}$ & $\begin{array}{c}\text { Chi2(22) }=4894,2 \\
3\end{array}$ & $\begin{array}{c}\text { Chi2(22)=11423, } \\
01\end{array}$ & Chi2(22) $=916,21$ \\
\hline & 0,00 & 0,00 & 0,00 & 0,00 \\
\hline \multirow{2}{*}{$\begin{array}{l}\text { Intra-individual } \\
\text { autocorrelation }\end{array}$} & $F(1,21)=48,771$ & $F(1,21)=53,815$ & $F(1,21)=52,019$ & $F(1,21)=53,237$ \\
\hline & 0,00 & 0,00 & 0,00 & 0,00 \\
\hline Conclusion & $\begin{array}{l}\text { Presence of fixed } \\
\text { individual } \\
\text { effects, inter- } \\
\text { individual } \\
\text { heteroscedasticit } \\
\text { y, and intra- } \\
\text { individual }\end{array}$ & $\begin{array}{l}\text { Presence of } \\
\text { random } \\
\text { individual } \\
\text { effects, inter- } \\
\text { individual } \\
\text { heteroscedasticit } \\
\text { y, and intra- }\end{array}$ & $\begin{array}{l}\text { Presence of } \\
\text { random } \\
\text { individual } \\
\text { effects, inter- } \\
\text { individual } \\
\text { heteroscedasticit } \\
y \text {, and intra- }\end{array}$ & $\begin{array}{l}\text { Presence of } \\
\text { individual } \\
\text { effects, inter- } \\
\text { individual } \\
\text { heteroscedasticit } \\
\text { y, and intra- } \\
\text { individual }\end{array}$ \\
\hline
\end{tabular}




\begin{tabular}{|c|c|c|c|c|}
\hline Test & Model 0 & Model 1 & Model 2 & Model 3 \\
\hline & "Without KH" & $\begin{array}{c}\text { "Mincerian } \\
\text { approach to KH" }\end{array}$ & "PCA approach" & $\begin{array}{l}\text { "PCA approach } \\
\text { with } \\
\text { decomposition } \\
\text { of } \mathrm{KH} "\end{array}$ \\
\hline & autocorrelation & $\begin{array}{c}\text { individual } \\
\text { autocorrelation }\end{array}$ & $\begin{array}{c}\text { individual } \\
\text { autocorrelation }\end{array}$ & autocorrelation \\
\hline & $\begin{array}{c}\text { GLS with } \\
\text { necessary } \\
\text { corrections }\end{array}$ & $\begin{array}{l}\text { GLS with } \\
\text { necessary } \\
\text { corrections }\end{array}$ & $\begin{array}{c}\text { GLS with } \\
\text { necessary } \\
\text { corrections }\end{array}$ & $\begin{array}{c}\text { GLS with } \\
\text { necessary } \\
\text { corrections }\end{array}$ \\
\hline
\end{tabular}

7.4.2. Tests on the Convergence Equation

\begin{tabular}{|c|c|c|c|c|}
\hline Test & Model 0 & Model 1 & Model 2 & Model 3 \\
\hline & "Without KH" & $\begin{array}{c}\text { "Mincerian } \\
\text { approach to KH" }\end{array}$ & "PCA approach" & $\begin{array}{l}\text { "PCA approach } \\
\text { with } \\
\text { decomposition } \\
\text { of } \mathrm{KH} "\end{array}$ \\
\hline \multirow{2}{*}{ Presence of individual effects } & $F(21,107)=3,51$ & $F(21,106)=3,50$ & $F(21,105)=3,52$ & $F(21,103)=3,35$ \\
\hline & 0,00 & 0,00 & 0,00 & 0,00 \\
\hline \multirow{2}{*}{$\begin{array}{c}\text { Fixed effects vs. random } \\
\text { effects }\end{array}$} & $\operatorname{Chi} 2(3)=13,83$ & Chi2(4)=16,63 & $\operatorname{Chi} 2(5)=18,01$ & $\operatorname{Chi} 2(7)=15,06$ \\
\hline & 0,00 & 0,0023 & 0,0029 & 0,035 \\
\hline \multirow{2}{*}{ Heteroscedasticity } & $\mathrm{LM}=131,69$ & $\mathrm{LM}=131,69$ & $\mathrm{LM}=131,70$ & $\mathrm{LM}=131,74$ \\
\hline & 0,00 & 0,00 & 0,00 & 0,00 \\
\hline \multirow{2}{*}{$\begin{array}{c}\text { Intra-individual } \\
\text { heteroscedasticity }\end{array}$} & $\begin{array}{c}\text { Chi2(22)= } \\
1045,73\end{array}$ & Chi2(22)=729,54 & Chi2(22)=604,75 & Chi2(22) $=918,13$ \\
\hline & 0,00 & 0,00 & 0,00 & 0,00 \\
\hline \multirow{2}{*}{$\begin{array}{l}\text { Intra-individual } \\
\text { autocorrelation }\end{array}$} & $F(1,21)=16,495$ & $F(1,21)=20,085$ & $F(1,21)=18,298$ & $F(1,21)=18,949$ \\
\hline & 0,00 & 0,00 & 0,00 & 0,00 \\
\hline \multirow[t]{2}{*}{ Conclusion } & $\begin{array}{l}\text { Presence of fixed } \\
\text { individual } \\
\text { effects, inter- } \\
\text { individual } \\
\text { heteroscedasticit } \\
\text { y, and intra- } \\
\text { individual } \\
\text { autocorrelation }\end{array}$ & $\begin{array}{l}\text { Presence of fixed } \\
\text { individual } \\
\text { effects, inter- } \\
\text { individual } \\
\text { heteroscedasticit } \\
\text { y, and intra- } \\
\text { individual } \\
\text { autocorrelation }\end{array}$ & $\begin{array}{l}\text { Presence of fixed } \\
\text { individual } \\
\text { effects, inter- } \\
\text { individual } \\
\text { heteroscedasticit } \\
\text { y, and intra- } \\
\text { individual } \\
\text { autocorrelation }\end{array}$ & $\begin{array}{l}\text { Presence of fixed } \\
\text { individual } \\
\text { effects, inter- } \\
\text { individual } \\
\text { heteroscedasticit } \\
y \text {, and intra- } \\
\text { individual } \\
\text { autocorrelation }\end{array}$ \\
\hline & $\begin{array}{c}\text { GLS with } \\
\text { necessary } \\
\text { corrections }\end{array}$ & $\begin{array}{c}\text { GLS with } \\
\text { necessary } \\
\text { corrections }\end{array}$ & $\begin{array}{c}\text { GLS with } \\
\text { necessary } \\
\text { corrections }\end{array}$ & $\begin{array}{c}\text { GLS with } \\
\text { necessary } \\
\text { corrections }\end{array}$ \\
\hline
\end{tabular}

